\title{
Kolaborasi dan Sinergitas Antar Stakeholder dalam Pembangunan Berkelanjutan Sektor Pariwisata Di Kebun Raya Cibinong
}

\author{
Mahardhika Berliandaldo \\ Lembaga Ilmu Pengetahuan Indonesia \\ Achmad Chodiq \\ Lembaga Ilmu Pengetahuan Indonesia \\ Driszal Fryantoni \\ Lembaga Ilmu Pengetahuan Indonesia \\ *aldo.vega17@gmail.com
}

\begin{abstract}
Abstrak
Perkembangan sektor pariwisata saat ini membutuhkan keterlibatan berbagai stakeholder dari berbagai kalangan. Peran stakeholder disesuaikan dengan tugas dan tanggungjawab yang dimiliki agar hasil yang dicapai dapat berjalan secara optimal. Penelitian ini bertujuan untuk mengidentifikasi para stakeholder yang terlibat dan melakukan Analisa peran stakeholder berdasarkan pengaruh (power) dan kepentingannya (interest), Selain itu, dilakukan analisis keterlibatan masing-masing stakeholder serta mengukur dampak yang terjadi atas pelaksanaan kolaborasi dan sinergitas antar stakeholder. Hasil identifikasi stakeholder menunjukan pengelompokan kedalam dua konteks yaitu stakeholder primer yang terdiri dari LIPI dan Pemerintah Kabupaten Bogor, serta stakeholder sekunder yang terdiri dari Kementerian PUPR, Dinas PUPR Kab. Bogor, Mitra Pengelola Kebun Raya, dan Pelaksana TJSL Kab. Bogor. Untuk mendukung keberhasilan dalam pengembangan pariwisata, maka dilakukan analisis peran dari masing-masing stakeholder. Hasil analisis menunjukan para stakeholder terbagi kedalam empat kategori analisis peran berdasarkan kepentingan dan Pengaruh, yakni sebagai Subyek (subjects), sebagai Pemain Kunci (key player), sebagai Pengikut Lain (crowd), dan sebagai Pendukung (Contest Setters). Pembagian peran dan tanggung jawab masing-masing stakeholder dapat mempercepat proses pembangunan sektor pariwisata yang dilakukan di Kebun Raya Cibinong. Dampak dari adanya pembangunan dan pengembangan Kebun Raya Cibinong dapat terlihat dari segi ekonomi, sosial, dan lingkungan. Hal yang paling jelas terlihat adalah adanya peningkatan penyerapan tenaga kerja dan pertumbuhan ekonomi sekitar Kawasan kebun raya, sehingga akan meningkatkan kesejahteraan masyarakat pada umumnya.
\end{abstract}

Kata Kunci: Kolaborasi dan Sinergitas, Stakeholder, Kebun Raya Cibinong.

\section{Pendahuluan}

Perkembangan sektor pariwisata di Indonesia beberapa tahun terakhir ini mengalami peningkatan yang cukup tajam dan signifikan, akan tetapi dengan adanya wabah virus yang terjadi saat ini menjadi sektor pariwisata bergejolak dengan ditunjukan penurunan jumlah wisatawan lokal maupun asing selama beberapa bulan terakhir. Dengan adanya pola kebiasaan baru saat ini, perlu adanya tatanan baru dalam skema pariwisata sehingga dapat meningkatkan gairah baru pada sektor pariwisata. Kebutuhan wisata dialam bebas saat ini menjadi daya Tarik 
tersendiri bagi masyarakat. Keinginan setiap masyarakat untuk dapat menghirup udara yang sangat segar menjadi magnet tempat wisata seperti Kebun Raya. Kebun Raya Cibinong yang memiliki berbagai macam tumbuhan dari berbagai daerah dapat memberikan daya tarik yang menyenagkan bagi para pengunjung setiap harinya.

Namun demikian, Kebun Raya Cibinong tidak dapat berdiri sendiri dalam melakukan pengembangan pariwisata, sehingga membutuhkan stakeholder lainnya yang dapat membantu terlaksananya program pengembangan Kebun Raya Cibinong. Hal serupa terjadi pada pengembangan pariwisata di makam sunan ampel kota Surabaya (Jawa Timur) yang membutuhkan kolaborasi antar dinas pariwisata kota surabaya, Yayasan pengelola, dan masyarakat (Amsyari, 2018). Kebutuhan akan kolaborasi antar stakeholder juga dibutuhkan pada pariwisata di lampung. Stakeholder yang terlibat dalam pengembangan Wisata Talang Air di Kelurahan Pajaresuk Kabupaten Pringsewu adalah individu, kelompok atau organisasi, dan lembaga Pemerintah Daerah Kabupaten Pringsewu serta Pemerintah Daerah Provinsi Lampung yang saling bekerjasama dan berkoordinasi dalam merealisasikan serta mengembangkan talang air peninggalan kolonial Belanda yang ada di Kabupaten Pringsewu menjadi salah satu pariwisata daerah Kabupaten Pringsewu (Hidayah et al., 2019). Kebutuhan tata kelola kolaboratif dalam membangun suatu pariwisata sangatlah dibutuhkan agar dapat memberikan pembangunan yang berkelanjutan. Pengaturan tata kelola kolaboratif berpotensi dapat membentuk pengetahuan dari berbagai sumber yang lebih besar dan menyediakan akses yang lebih luas ke masyarakat dan institusi lainnya (Kuhn, 2016). Untuk mewujudkan pengembangan pariwisata berkelanjutan, tetap penting membangun persepsi khusus tentang konsep di antara pemangku kepentingan, tujuan dimasukkan ke dalam setiap upaya untuk mengembangkan pariwisata berkelanjutan perlu dilakukan sinergi yang kuat agar dapat tercapai tujuannya (Dabphet, 2006).

Sinergi dalam kepariwisataan adalah hal penting dalam mengembangkan potensi pariwisata suatu destinasi, serta model sinergi menjadi suatu kebutuhan untuk menuntun stakeholder pariwisata dalam membangun destinasi (Junaid, 2019). Dengan adanya konsep pengembangan dan model masterplan Kebun Raya Cibinong, peran stakeholder dapat disesuaikan dengan tugas dan fungsinya masing-masing. Berbagai peran dan tanggungjawab secara teknis dari setiap stakeholder dapat membantu terlaksananya pengembangan kebun raya cibinong, dalam kondisi yang diharapkan bagi masyarakat dan seluruh pihak yang terlibat dalam pengembangan ekowisata di Kebun Raya Cibinong. Dalam melaksanakan konsep pengembangan ekowisata tentunya diperlukan partisipasi yang cukup baik dari para stakeholder yang terlibat dalam pengelolaan ekowisata, sehingga hubungan antar organisasi, kolaborasi dan kerjasama dalam pengelolaan ekowisata merupakan suatu hal yang penting. Pelaksanaan penggelolaan ekowisata tentunya tidak dapat terlaksana apabila para stakeholder yang terlibat ini tidak memiliki kemampuan untuk melaksanakan dan mengembangkannya. Dengan banyaknya kepentingan yang dimiliki oleh stakeholder yang terlibat, maka diperlukan kerjasama yang kuat antara para stakeholder tersebut (Pamungkas, 2013).

Pelaksanaan kolaborasi dalam pengembangan Kawasan yang dilakukan para stakeholder tidak selalu berjalan dengan baik. Salah satu permasalahan yang ada yaitu tidak semua stakeholder yang terlibat dalam pengembangan kawasan sudah melaksanakan perannya secara maksimal (Mahfud, 2015). Padahal kerjasama antar stakeholders termasuk masyarakat sangat berpengaruh dalam pengembangan suatu Kawasan pariwisata. Untuk itu dibutuhkan suatu proses pembentukan kepercayaan antar setiap stakeholders yang merupakan syarat untuk membangun kolaborasi yang solid antar setiap actor (Amsyari, 2018). Hal ini dapat dilakukan dengan berbagi peran dan tanggungjawab dari masing-masing stakeholder agar dapat melaksanakan fungsinya secara tepat dan membuat pembangunan Kawasan pariwisata dapat berjalan sesuai rencana. 
Sangat penting untuk menganalisis stakeholders yang terlibat dalam pembangunan Kebun Raya Cibinong. Penelitian ini bertujuan untuk mengidentifikasi para stakeholder yang terlibat dan melakukan Analisa peran stakeholder berdasarkan pengaruh (power) dan kepentingannya (interest), Melalui analisis stakeholders akan tergambar kepentingan dan Pengaruh dari masing-masing stakholders. Analisa tersebut juga nantinya akan membantu dalam memobilisasi sumberdaya lokal serta dapat mengetahui unsur keterlibatan dan dampak yang dihasilkan dari pelaksanaan kolaborasi dan sinergisitas antar stakeholder. Selain itu, dilakukan analisis keterlibatan masing-masing stakeholder serta mengukur dampak yang terjadi atas pelaksanaan kolaborasi dan sinergitas antar stakeholder.

\section{Landasan Teori}

\section{Stakeholder}

Stakeholder adalah individu, kelompok organisasi baik laki-laki atau perempuan yang memiliki kepentingan, terlibat atau dipengaruhi (positive atau negative) oleh suatu kegiatan program pembangunan (Sjaifudian, 2003). (Freeman et al., 2007) membagi pemangku kepentingan (Stakeholders) menjadi dua fase, yaitu Stakeholders primer dan Stakeholders sekunder. Stakeholders primer adalah yang terkait langsung dengan perusahaan seperti pelanggan, investor, karyawan, pemasok dan masyarakat, sementara Stakeholders sekunder yang tidak terkait langsung seperti media, pemerintah, pesaing, organisasi konsumen dan kelompok terkait lainnya. Seperti yang umumnya diketahui Stakeholders diakui sebagai pemegang saham dan investor lainnya, karyawan, pemasok, pelanggan, masyarakat dan pemerintah.

Pembagian stakeholders ini berbeda dari yang diklasifikasikan oleh (Mitchell et al., 1997). Mereka membagi stakeholders berdasarkan atribut yang dimiliki oleh stakeholders. Ada tiga jenis atribut yang dimiliki oleh stakeholders, ketiga atribut ini adalah:

a. Power. Power (Kekuasaan) adalah kemampuan pemangku kepentingan untuk mempengaruhi orang lain untuk melakukan sesuatu.

b. Legitimasi. Legitimasi mengacu pada perilaku penerimaan pemangku kepentingan di bidang hukum dan etika sosial.

c. Urgensi. Didefinisikan sebagai sejauh mana pemangku kepentingan memiliki tingkat kepentingan pada pemangku kepentingan lain.

Berbagai kelompok maupun organisasi ikut serta mendukung pengelolaan ekowisata dengan berbagai potensi yang dimiliki. Enam kelompok stakeholder utama yang dapat mempengaruhi pola pengembangan dan kebijakan pariwisata dalam kawasan dengan keanekaragaman hayati yang siginifikan secara global (Dwyer \& Edwards, 2000) adalah sebagai berikut:

a. Sektor publik (badan pemerintahan lokal, nasional, regional, dan global);

b. Sektor privat;

c. Lembaga donor bilateral dan multilateral;

d. Lembaga Swadaya Masyarakat (LSM);

e. Komunitas lokal dan penduduk terasing;

f. Konsumen.

\section{Collaborative Governance}

Pemerintah tidak hanya mengandalkan pada kapasistas internal yang dimiliki dalam penerapan sebuah kebijakan dan pelakasanaan program (Febrian, 2016). Pemerintah pada 
dasarnya perlu mendengarkan suara publik untuk dapat memutuskan tindakan atau kebijakan apa yang perlu dirancang. Oleh karena itu, perlu melibatkan warga dalam merancang sebuah kebijakan. Dalam hal ini proses dan struktur pengambilan keputusan dan manajemen kebijakan publik yang melibatkan orang secara konstruktif di seluruh batas-batas lembaga publik, tingkat pemerintahan, dan / atau lingkup publik, swasta dan sipil untuk melaksanakan tujuan publik yang tidak dapat dicapai (Emerson et al., 2012).

Studi kolaborasi antara pemangku kepentingan yang pada akhirnya kita sebut sebagai pemerintah kolaborasi, menyiratkan bahwa pemerintah bekerja antara berbagai pemangku kepentingan, lembaga dan bahkan warga negara untuk menciptakan kebijakan yang lebih baik bagi semua orang (Yasintha, 2020). Collaborative governance berbasis pada tujuan untuk memecahkan bersama permasalahan atau isu tertentu dari para pihak yang terkait, pihak tersebut tidak hanya berbatas pada instansi pemerintah dan non pemerintah, karena dalam prinsip tata kelola pemerintahan yang baik, melibatkan masyarakat sipil dalam perumusan dan pengambilan keputusan (Febrian, 2016). Model Collaborative Governance yaitu Kondisi awal dalam suatu kolaborasi dipengaruhi oleh beberapa fenomena, yaitu para stakeholders memiliki kepentingan dan visi bersama yang ingin dicapai, sejarah kerjasama dimasa lalu, saling menghormati kerjasama yang terjalin, kepercayaan masing-masing stakeholders, ketidakseimbangan kekuatan, sumber daya, dan pengetahuan (Ansell \& Gash, 2007).

Keterbatasan kemampuan, sumberdaya maupun jaringan yang menjadi faktor pendukung terlaksananya suatu program atau kebijakan, mendorong pemerintah untuk melakukan kerjasama dengan berbagai pihak, baik dengan sesama pemerintah, pihak swasta maupun masyarakat dan komunitas masyatakat sipil sehingga dapat terjalin kerjasama kolaboratif dalam mencapai tujuan program atau kebijakan (Purwanti, 2016). Berdasarkan paparan diatas dapat diketahui bahwa pemerintah kolaboratif adalah kemitraan publik - swasta, dimana pada dasarnya merupakan inisiasi kolaboratif antara negara dan non - negara, aktor komersial dan non - profit yang lahir dari partisipasi pragmatisme. Kolaborasi tersebut merupakan bentuk kerjasama yang melibatkan beberapa pihak yang kemudian disatukan pada suatu pandangan atau tujuan yang sama secara nyata. Hal ini menjadikan sistem pemerintahan kolaboratif memiliki peranan tersendiri antar elemen didalamnya. Terdapat Empat jenis hubungan kolaboratif antara aktor menjadi nyata (Wanna, 2008):

- Kolaborasi di dalam pemerintahan, melibatkan berbagai agen dan pemain.

- Kolaborasi antara pemerintah, melibatkan instansi dari berbagai yurisdiksi.

- Kolaborasi antara pemerintah dan penyedia barang dan jasa pihak ketiga eksternal.

- Kolaborasi antara pemerintah dan warga negara.

\section{Metode Penelitian}

Penelitian ini merupakan penelitian yang bersifat deskriptif dengan menggunakan pendekatan kualitatif. Dalam metode ini analisis data yang dilakukan bersifat induktif berdasarkan fakta-fakta yang ditemukan dilapangan dan kemudian disusun menjadi sebuah konsep pengembangan (Sugiyono, 2010). Dalam penelitian ini dibatasi pada empat fokus penelitian yaitu: 1) melakukan identifikasi para stakeholder yang terlibat dalam pengembangan pariwisata di Kebun Raya Cibinong, 2) menyusun analisis peran dari masing-masing stakeholder, 3) menganalisa bentuk keterlibatan dari para stakeholder, dan 4) melihat dampak yang terjadi dari adanya kolaborasi dan sinergitas antar stakeholder. Selanjutnya, data yang telah dianalisis akan disajikan dan dilakukan penarikan kesimpulan sehingga menghasilkan sebuah konsep pengembangan pariwisata dengan pendekatan kolaborasi dan sinergitas antar stakeholder. 


\section{Hasil Dan Pembahasan}

\section{Identifikasi Stakeholder}

Pengembangan pariwisata saat ini menjadi salah satu program dari setiap daerah di Indonesia. Berkembangnya pariwisata akan memberikan dampak positif bagi sekitarnya. Untuk mengembangan pariwisata dibutuhkan peran dari seluruh pemangku kebijakan baik yang berasal dari pusat maupun daerah serta dapat melibatkan pihak swasta agar dapat meningkatkan nilai dari pariwisata tersebut. Kebun Raya Cibinong berada di Kawasan Cibinong Science Center-Botanical Garden yang berlokasi di Kabupaten Bogor dan berdekatan dengan sentral pemerintahan kabupaten bogor. Lokasi tersebut berada diantara Kebun Raya Bogor dan Kota Jakarta, sehingga dapat dengan mudah untuk dijangkau oleh elemen masyarakat sekitarnya.

Peran stakeholder sangat dibutuhkan untuk membantu pengembangan sektor pariwisata, salah satu stakeholder yang sangat berperan dalam sektor tersebut adalah pemerintah, akan tetapi pemerintah memiliki keterbatasan dalam prosesnya sehingga dibutuhkan stakeholder lain yang memiliki kemampuan dan kapabilitas dalam mendukung pengembangan pariwisata khususnya Kebun Raya Cibinong. Identifikasi stakeholder dalam konteks ini menggunakan 2 (dua) pendekatan yaitu stakeholder primer dan stakeholder sekunder (Wakka, 2014). Stakeholder primer ini berhubungan langsung dengan pembuatan kebijakan, program, dan proyek, stakeholder tersebut merupakan penentu utama dalam kegiatan pengambilan keputusan. Sedangkan, stakeholder sekunder adalah pihak yang tidak berkaitan langsung terhadap suatu kebijakan, program, dan proyek. Namun stakeholder sekunder punya keprihatinan dan kepedulian sehingga ikut menyuarakan pendapat yang bisa mempengaruhi sikap stakeholder utama dan keputusan legal pemerintah.

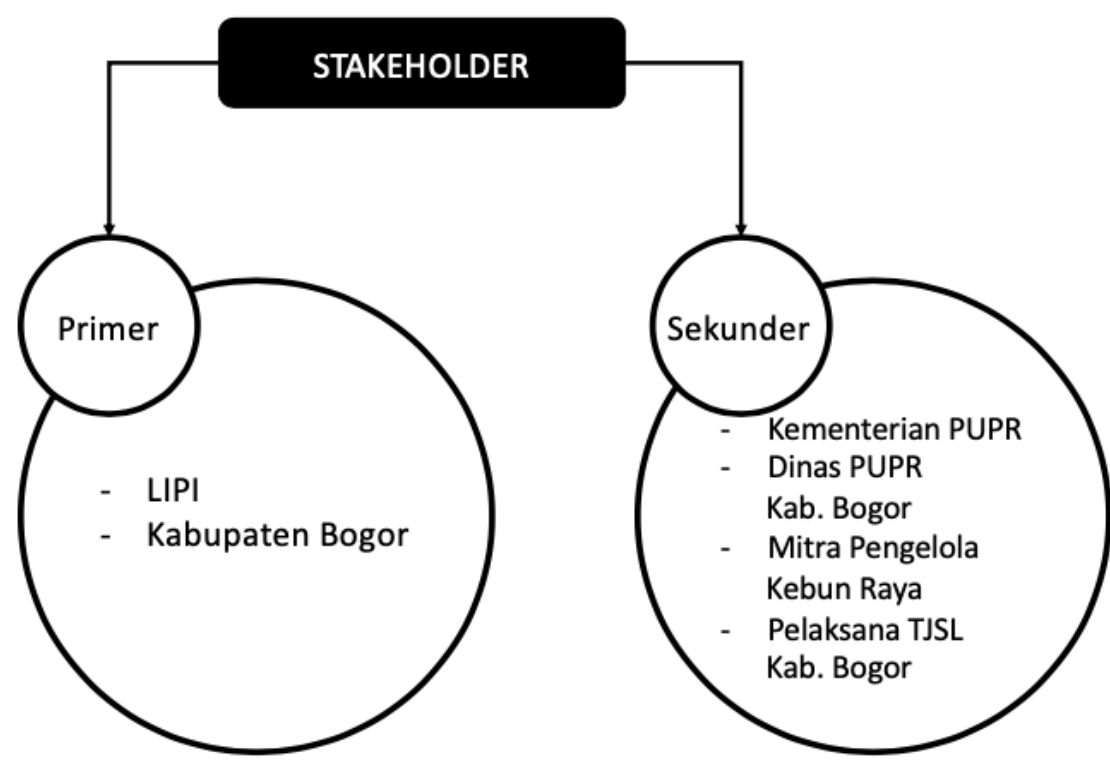

Gambar 1. Identifikasi Stakeholder untuk Pengembangan Pariwisata Kebun Raya Cibinong (Sumber: modifikasi dari (Wakka, 2014)

Adanya beberapa stakeholder yang terlibat dalam pengembangan sektor pariwisata di Kebun Raya Cibinong menunjukan keterlibatan dan kepentingannya masing-masing. Wisata 
seperti halnya Kebun Raya Bogor, pengembangan dilakukan atas keterlibatan berbagai pihak agar memberikan kesan positif bagi masyarakat. Berbagai macam peran pembangunan wisata yang telah dilakukan baik pengembangan objek wisata maupun pengembangan fasilitas pendukung lainnya yang menunjang pengembangan pariwisata Kebun Raya Cibinong. Berdasarkan klasifikasi stakeholder sebagaimana dikemukakan diatas, maka stakeholder primer dan stakeholder sekunder terdiri dari:

a. Stakeholder Primer

Pihak yang memiliki kepentingan langsung terkait pengembangan pariwisata di Kebun Raya Cibinong dapat dikatakan sebagai Stakeholder Primer. Stakeholder tersebut akan terlibat secara langsung dalam pengembangan sektor pariwisata, sehingga dapat menciptakan nilai positif bagi pengembangan daerah sekitarnya. Berikut ini adalah stakeholder primer dalam konteks pengembangan Kebun Raya Cibinong, yaitu sebagai berikut:

1) Lembaga Ilmu Pengetahuan Indonesia (LIPI). Peran LIPI dalam hal ini sangat jelas, diantaranya Kebun Raya Cibinong berada di Kawasan Litbang yang berlokasi di Cibinong yang merupakan salah satu Kawasan yang berada dibawah naungan LIPI. Luas lahan yang digunakan oleh Kebun Raya Cibinong sebesar 30 Ha. Dalam pengembangannnya, Kebun Raya Cibinong berada dibawah koordinasi Pusat Konservasi dan Tumbuhan Kebun Raya Bogor. Terkait konservasi tumbuhan, pengembangan Kebun Raya Cibinong terus ditata secara rapi agar sesuai dengan masterplan kebun raya yang dikembangkan. Dalam konteks Pengembangan Pariwisata, Kebun Raya Cibinong merupakan program peningkatan edukasi dan ekowisata bagi masyarakat dan stakeholder lainnya.

2) Pemerintah Kabupaten Bogor. Pemerintah daerah memiliki kepentingan terhadap pengembangan pariwisata dalam meningkatkan kesejahteraan masyarakat sekitarnya. Kebun Raya Cibinong berada dalam yuridiksi kabupaten bogor, sehingga dalam pengembangannya membutuhkan andil dan peran pemerintah daerah agar sesuai dengan program pemerintah daerah.

\section{b. Stakeholder Sekunder}

Pihak lainnya yang memiliki minat atau kepentingan secara tidak langsung dalam membantu pengembangan pariwisata Kebun Raya Cibinong dapat dikatakan sebagai Stakeholder sekunder. Para pihak tersebut akan mendukung demi kemajuan pariwisata dan kenyaman masyarakat sekitar dalam pengembangan sektor pariwisata. Berikut ini adalah stakeholder sekunder dalam konteks pengembangan Kebun Raya Cibinong, yaitu sebagai berikut:

1) Kementerian PUPR. Program pembangunan Kebun Raya telah masuk dalam koridor roadmap pembangunan kebun raya yang telah digagas oleh Kementerian PUPR dan LIPI. Penyediaan infrastruktur penunjang untuk kebun raya dapat dilakukan oleh Kementerian PUPR yang telah sesuai dengan masterplan pengembangan kebun raya yang telah disetujui oleh para pihak.

2) Dinas PUPR Kab. Bogor. Pembangunan infrastruktur pendukung Kebun Raya Cibinong telah menjadi ketetapan program Bupati terpilih untuk mendukung kelancaran pengembangan pariwisata di Kebun Raya Cibinong. Pengembangan sarana pendukung tersebut dapat juga dirasakan oleh masyarakat sekitar dalam beraktifitas sehari-hari, sehingga hal tersebut dapat meningkatkan nilai positif bagi kemajuan daerah.

3) Mitra Pengelola Kebun Raya. Seperti halnya Kebun Raya Bogor dan tiga kebun raya lainnya yang dimiliki oleh LIPI, pengelolaan kebun raya cibinong akan dilimpahkan kepihak lainnya yaitu mitra sebagai pengelola dan penanggung jawab pengelolaan Kebun Raya Cibinong. Tujuan dari hal tersebut adalah untuk membantu dalam meningkatkan daya 
Tarik pariwisata bagi Kebun Raya Cibinong sehingga kedepannya dapat memberikan kesan positif bagi pengunjung kebun raya.

4) Pelaksana TJSL Kab. Bogor. TJSL atau Tanggung Jawab Sosial dan Lingkungan merupakan salah satu program pemerintah kabupaten Bogor untuk membantu masyarakat kabupaten bogor melalui program CSR dari perusahaan-perusahaan sekitarnya. Salah satu program TJSL yang dilakukan oleh pihak perusahaan di sekitar Kebun Raya Cibinong yaitu melaksanakan program lanjutan berupa infrastruktur pendukung dalam pengembangan jalan lingkar Kebun Raya Cibinong. Kedepannya, program TJSL tersebut akan bersinergi dalam meningkatkan kunjungan pariwisata di Kabupaten Bogor.

\section{Analisis Peran Stakeholder}

Keberhasilan dalam pengembangan pariwisata di Kebun Raya Cibinong tidak terlepas dari peran para stakeholder yang saling bekerjasama, bersinergi, dan berkolaborasi untuk mencapai keberlanjutan pembangunan Kebun Raya Cibinong. Pendekatan kolaborasi antar stakeholder mulai muncul sebagai respon atas tuntutan kebutuhan akan manajemen pengelolaan sumber daya yang baru untuk meraih hasil yang maksimal dan sesuai yang diharapkan. Dalam hal ini, semua pihak yang terlibat memposisikan dirinya sama atau sesuai dengan perannya masing-masing, sehingga saling menghormati dan menghargai dan tidak akan mucul konflik dikemudian hari. Dengan saling bersinergi dalam mencapai tujuan pengembangan pariwisata, maka semua peran yang dilakukan oleh masing-masing stakeholder akan memiliki Pengaruh dan kepentingan masing-masing. Sehingga hal tersebut dapat saling membantu dalam pembangunan pariwisata di Kebun Raya Cibinong.

Pembangunan sektor pariwisata terkait pengembangan Kebun Raya tidak hanya dilihat dari aspek pembangunan infrastruktur semata, melainkan dari aspek membangun kesadaran, pemahaman, sikap dan tindakan dalam upaya menyelamatkan keanekaragaman hayati di Indonesia. Dalam studi kebijakan, analisis peran stakeholder dilakukan untuk mengungkapkan kepentingan dan pengaruh (peranan) para stakeholder (Hidayah et al., 2019). Analisis peran pemangku kepentingan (stakeholder) dimulai dengan menyusun stakeholder pada matriks dua kali dua menurut interest (minat) stakeholder terhadap suatu masalah dan power (kekuasaan) stakeholder dalam mempengaruhi masalah tersebut (Hardiansyah, 2012). Memetakan stakeholder akan membantu pengembangan kebun raya cibinong dapat dilakukan secara optimal. Berdasarkan kekuasaan dan kepentingan yang dimiliki oleh setiap stakeholder maka dapat dikategorikan seperti gambar berikut: 
INOBIS: Jurnal Inovasi Bisnis dan Manajemen Indonesia Volume 04, Nomor 02, Maret 2021

Mahardhika Berliandaldo, Achmad Chodiq, Driszal Fryantoni

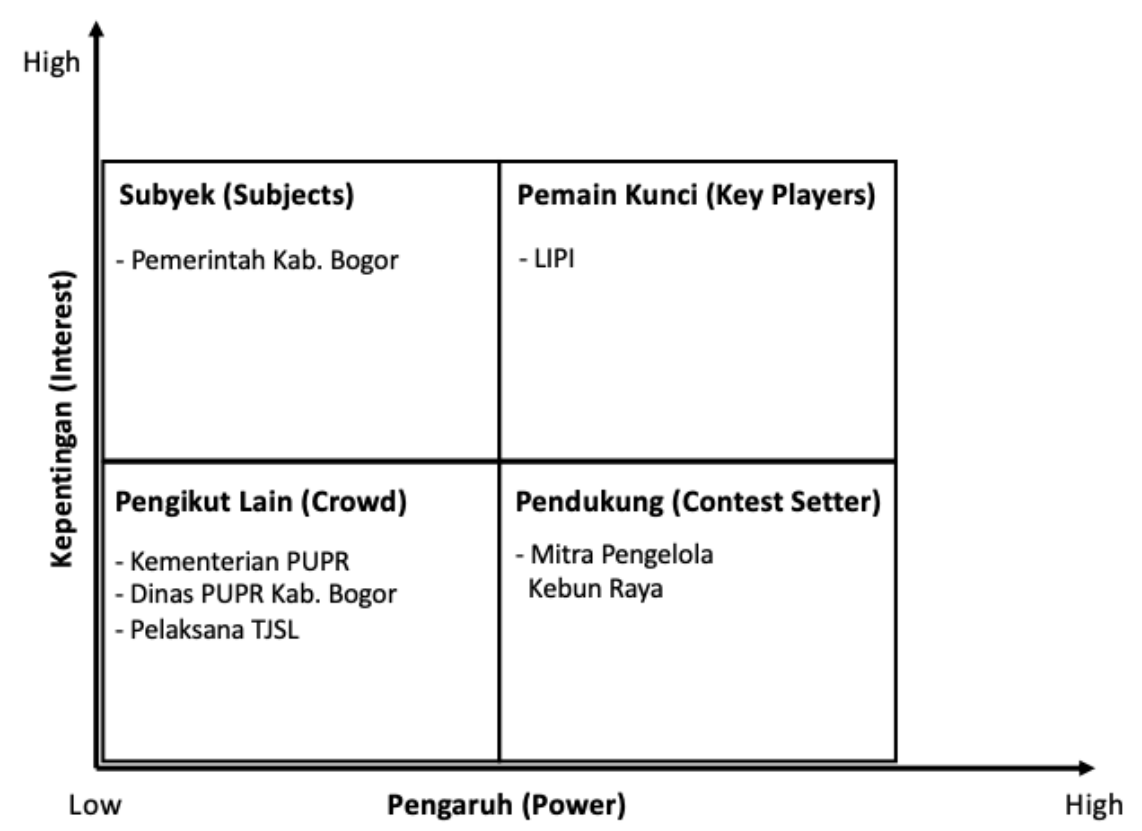

Gambar 2. Matriks Analisis Peran Stakeholder Kebun Raya Cibinong (Sumber: modifikasi dari (Bryson, 2004)

Berdasarkan gambar diatas, terdapat empat jenis kategori analisis peran stakeholder berdasarkan kepentingan dan Pengaruh, yaitu sebagai berikut:

a. Subyek (Subjects). Stakeholder dengan tingkat kepentingan (interest) yang tinggi tetapi memiliki Pengaruh (power) yang rendah. Dalam kategori tersebut yang termasuk didalamnya adalah Pemerintah Kabupaten Bogor. Stakeholders ini memiliki kapasitas yang rendah dalam pencapaian tujuan, akan tetapi dapat menjadi berpengaruh dengan membentuk aliansi dengan stakeholders lainnya. Pemerintah daerah memiliki kepentingan yang sangat kuat dalam mensukseskan Kebun Raya Cibinong yaitu agar kunjungan wisata di daerah tersebut dapat meningkatkan perekonomian masyarakat sekitarnya. Walaupun dalam pengembangan Kebun Raya memiliki Pengaruh yang cukup rendah, pemerintah Kab. Bogor akan tetap bersinergi dan berkolaborasi dengan pihak LIPI dalam menjalankan program pengembangan Kebun Raya Cibinong.

b. Pemain Kunci (Key Players). Stakeholders dengan tingkat kepentingan (interest) dan pengaruh (power) yang tinggi. Yang termasuk kedalam kategori ini adalah LIPI. Hal ini dikarenakan LIPI yang memiliki roadmap pengembangan kebun raya di seluruh Indonesia, dan secara kebetulan, Kebun Raya Cibinong berada di Kawasan Cibinong Science Center yang dimiliki oleh LIPI.

c. Pengikut Lain (Crowd). Stakeholders dengan tingkat kepentingan (interest) dan pengaruh (power) yang rendah. Diperlukan sedikit pertimbangan untuk melibatkan stakeholders ini lebih jauh karena kepentingan dan pengaruh yang dimiliki biasanya berubah seiring berjalannya waktu. Stakeholders ini harus tetap dimonitor dan dijalin komunikasi dengan baik. Yang termasuk kedalam kategori ini adalah Kementerian PUPR, DInas PUPR Kab. Bogor, dan Pelaksana TJSL. Infrastruktur pendukung untuk Kebun Raya Cibinong dapat dikembangkan oleh Kementerian PUPR dan Dinas PUPR Kab. Bogor yang berkolaborasi dan bersinergi dalam menjalan program-programnya seiring dengan pengembangan Kebun Raya Cibinong. Selain itu, peran kedua pihak tersebut dapat membantu kemajuan pembangunan Kawasan sekitarnya, sehingga memberikan nilai postif 
demi kemajuan ekonomi, sosial, dan lingkungan. Dengan berkembangnya pembangunan sekitar Kawasan kebun raya, maka hal itu dapat membantu meningkat kesejahteraan masyarakat sekitar.

d. Pendukung (Contest Setters). Stakeholders dengan tingkat kepentingan (interest) yang rendah tetapi memiliki pengaruh (power) yang tinggi. Stakeholders ini dapat mendatangkan resiko sehingga keberadaannya perlu dipantau dan dikelola dengan baik. Stakeholders ini dapat berubah menjadi key players karena suatu peristiwa. Hubungan baik dengan stakeholder ini terus dibina. Untuk itu segala informasi yang dibutuhkan harus tetap diberikan sehingga mereka dapat terus berperan aktif dalam pencapaian tujuan. Yang termasuk kedalam kategori ini adalah Mitra Pengelola Kebun Raya. Mitra tersebut memiliki peran dalam mengembangan Kawasan didalam Kebun Raya Cibinong. Dengan diberikan tanggungjawab atas pengelolaan kebun raya, maka segala sesuatu terkait kebijakan dan pengaturan pengelolaan diserahkan sepenuhnya kepada pihak mitra, terkecuali konservasi tumbuhan. Dengan adanya mitra pun, pengelolaan kebun raya nantinya akan dibawa keranah yang lebih professional dan berdaya saiang dengan objek wisata sekitarnya, sehingga hal ini akan memberikan daya Tarik tersendiri bagi para pengunjung kebun raya.

\section{Bentuk Keterlibatan Stakeholder}

Pembangunan pariwisata di Kebun Raya Cibinong pada hakekatnya melibatkan para pemangku kebijakan yang memiliki program pengembangan dan pembangunan di Kebun Raya daerah. Pemerintah Pusat dalam hal ini adalah LIPI, sesuai Undang Undang No. 5 Tahun 1994 tentang Pengesahan United Nations Convention On Biological Diversity (Konvensi Perserikatan Bangsa Bangsa Mengenai Keanekaragaman Hayati) dan LIPI sebagai "scientific authority" di bidang konservasi dan keanekaragaman hayati di Indonesia. Dalam hal ini LIPI tidak mampu berjalan sendiri dalam mengembangkan Kebun Raya Cibinong sebagai Icon bagi Kabupaten Bogor, sehingga membutuhkan andil dan peran stakeholder lainnya untuk membangun wisata yang ramah, nyaman, menyenangkan. Setiap pemangku kepentingan memiliki peran dan fungsi masing-masing yang perlu dipahami (Redyanto et al., 2018), agar pengembangan wisata di Kebun Raya Cibinong dapat terwujud dan terlakasana dengan baik. Peran dari masing-masing stakeholder nampak lebih jelas terlihat dalam pengembangan Kebun Raya Cibinong. LIPI dalam hal ini pemilik lahan dari Kebun Raya Cibinong memiliki tugas dalam kebijakan konservasi tumbuhan di berbagai daerah salah satunya Cibinong. Dengan memiliki pengalaman dalam mengembangkan fungsi eduwisata dan ekowisata di Kebun Raya berbagai daerah, maka dapat dengan mudah untuk menerapkan kedua hal tersebut pada Kebun Raya Cibinong. LIPI dalam hal ini dibantu Pemerintah Kabupaten Bogor yang memiliki secara intens dan peduli terhadap pengembangan Kebun Raya Cibinong, sehingga dapat membantu dalam Menyusun regulasi terkait hal tersebut yang berfokus pada pengembangan pariwisata di Kebun Raya Cibinong. 


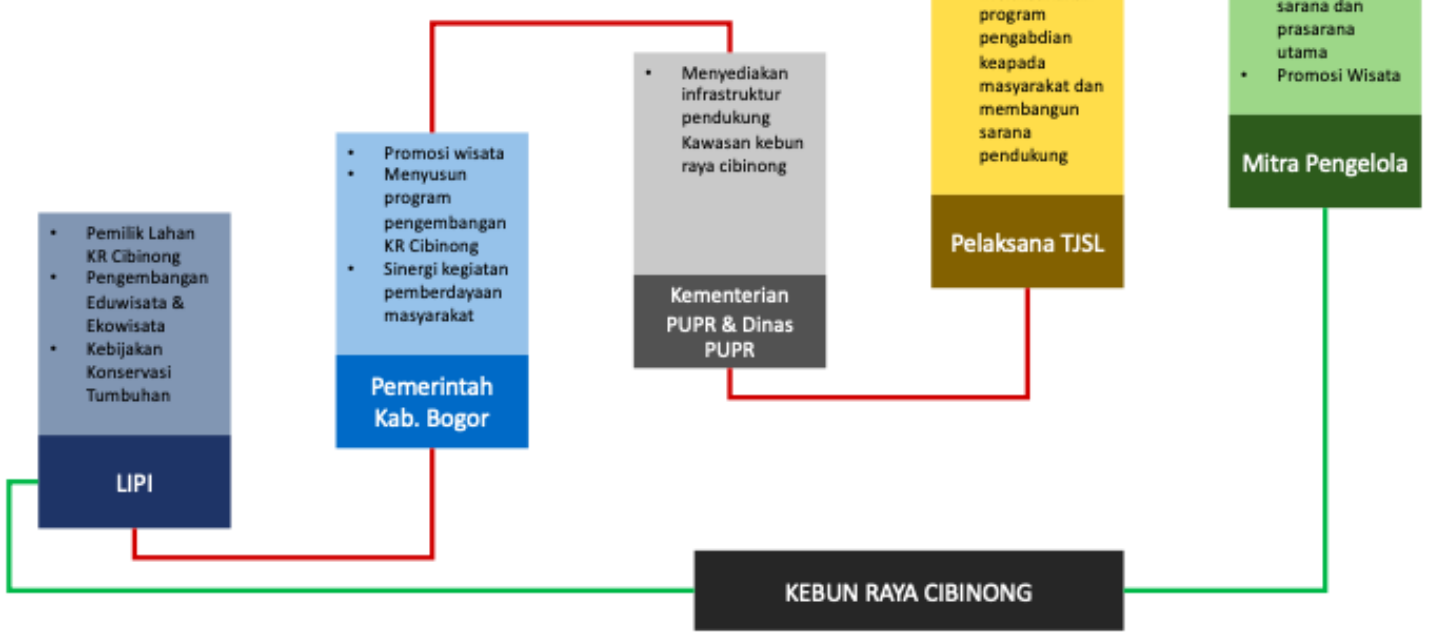

Gambar 3. Keterlibatan antar stakeholders dalam pengembangan Kebun Raya Cibinong (Sumber: Data diolah sendiri)

Pelaksanaan pembangunan infrastruktur pendukung hingga saat ini masih dibantu oleh Kementerian PUPR dan Dinas PUPR melalui program pengembangan Kebun Raya. Dengan bersinerginya kedua Lembaga tersebut, maka mempermudah tugas LIPI dalam menata kebun raya di cibinong. Adapula program TJSL yang digagas oleh Pemerintah Kab. Bogor untuk memanfaatkan sektor swasta dalam menjalankan program CSR nya di sekitar usaha mereka tersebut. Dengan bergabungnya pihak swasta dalam membangun kebun raya di cibinong, maka dapat memberikan signal positif bagi kemajuan sektor pariwisata di kabupaten bogor. Yang terakhir adalah dengan bergabungnya mitra pengelola sebagai penanggung jawab pengelolaan Kebun raya Cibinong. Hal ini akan memberikan manfaat yang baik bagi kemajuan dan perkembangan pariwisata di Kebun Raya Cibinong sehingga dapat meningkatkan nilai daya saing yang lebih. Pihak pengelola pun bertanggungjawab untuk menyediakan sarana prasarana utama yang menunjang pengembangan Kawasan di dalam kebun raya cibinong.

Dengan adanya keterlibatan seluruh stakeholder dalam membangun Kebun Raya Cibinong, maka dapat meningkatkan nilai jual Kawasan cibinong di mata nasional maupun internasional jika dapat dilakukan secara benar dan tepat. Kegiatan promosi pada dasaranya harus dilakukan secara intens oleh semua pihak agar dapat mendatangkan pengunjung dari berbagai penjuru daerah. Keseriusan seluruh stakeholder dalam menjalankan perannya masingmasing akan membantu kemajuan lingkungan sekitar untuk dapat tumbuh dan berkembang.

\section{Dampak dari Kolaborasi dan Sinergitas antar Stakeholder}

Dampak yang muncul dari adanya kolaborasi dan sinergitas antar stakeholder dalam membangun kebun raya cibinong agar dapat menjadi destinasi wisata yang bermanfaat bagi seluruh elemen, terdiri dari tiga unsur, yaitu sebagai berikut

a. Dampak Ekonomi

Dampak ekonomi yang akan timbul dari adanya pengembangan Kebun Raya Cibinong yakni salah satunya pembukaan lapangan pekerjaan, dengan adanya hal tersebut maka akan meningkatkan penyerapan tenaga kerja, secara tidak langsung akan menurunkan tingkat pengangguran dan juga meningkatkan pendapatan masyarakat. Adanya pengembangan 
desa wisata mampu membuka lapangan kerja baru dan lebih banyak (Khomzi et al., 2020). Hal lain yang muncul dari adanya Kebun Raya Cibinong ini adalah meningkatnya jumlah UMKM dari Kawasan penyangga Kebun Raya Cibinong. Selain itu juga, secara tidak langsung akan bermunculan para pedagang baik itu yang nantinya akan dikelola langsung oleh pihak mitra maupun yang tumbuh secara tidak sengaja di sekitar Kawasan kebun raya. Pertumbuhan ini akan meningkatkan kesejahteraan masyarakat sekitar, sehingga kedepannya perlu adanya penataan terkait para pedagang, UMKM, serta entrepreneur lainnya yang akan mencari nafkah dari pengembangan Kebun Raya Cibinong. Pemerintah Kabupaten Bogor dalam hal ini selaku regulator, dapat Menyusun suatu strategi pengembangan UMKM dan pemberdayaan masyarakat sehingga dapat meningkatkan perekonomian daerah secara tidak langsung.. Kejadian reel pengembangan objek wisata yang ditunjukkan dengan adanya dampak ekonomi terjadi di objek wisata yaitu peningkatan pendapatan bagi penduduk sekitar yang disebabkan jumlah kunjungan yang semakin meningkat, penduduk lokal memperoleh penghasilan dengan berjualan makanan dan minuman serta melalui jasa angkutan di sekitar lokasi tersebut serta pendapatan pemerintah akan meningkat apabila banyak wisatawan yang berkunjung untuk menikmati keindahan obyek wisata (Rizal et al., 2017).

b. Dampak Sosial

Dampak sosial yang timbul dari adanya pengembangan Kebun Raya Cibinong ini adalah adanya interaksi sosial antar seluruh stakeholder dengan masyarakat sekitar. Sebagai contoh Pihak LIPI dengan masyarakat sekitar akan terus bersinggungan terkait maraknya para pedagang dan UMKM yang tumbuh disekitaran Kawasan Cibinong Science CenterBotanical Garden. Selain itu, dengan adanya pariwisata tersebut dapat memberikan kesadaran bagi masyarakat sekitar untuk menata lingkungan sosialnya agar dapat terjada dan terkendali dengan baik, sehingga lingkungan disekitaran Kawasan dapat berkembang mengikuti pertumbuhan kebun raya cibinong. Dampak sosial positif lainnya yaitu penurunan kenakalan remaja, dikarena remaja yang pengangguran diberdayakan (Khomzi et al., 2020). Kenakalan remaja tidak hanya menjadi tanggung jawab bagi orang tua namun juga milik masyarakat sebagai tanggung jawab moral kehidupan, sehingga penurunan kenakalan remaja juga diperlukan (Rahmah, 2017). Pengembangan Kebun Raya Cibinong akan memberikan efek positif bagi masyarakat dilingkungan terdekat, hal ini dikarenakan akan menyerap tenaga kerja sebagai penopang SDM di Kebun Raya terlebih dahulu sebelum membuka lowongan pekerjaan secara resmi. Dengan begitu, efek sosial bagi pengembangan kebun raya akan mengutungkan kedua belah pihak. Pembangunan infrastruktur pendukung pun akan dinikmati oleh masyarakat sekitar dalam memanfaatkan jalan yang telah dikembangkan sebagai penunjang Kebun Raya Cibinong.

c. Dampak Lingkungan

Dampak lingkungan yang timbul dari adanya Kebun Raya Cibinong ini adalah terkait kepedulian lingkungan dalam menjaga kebersihan. Setelah adanya pengembangan ekowisata, terjadi perubahan perilaku dengan semakin sadarnya masyarakat terhadap kebersihan lingkungan karena semakin banyaknya wisatawan, semakin banyak pula sampah yang ada, sehingga mulailah masyarakat untuk melakukan pengelolaan terhadap sampah yang ada (Hijriati \& Mardiana, 2015). Menjaga kebersihan pada dasarnya menjadi tanggungjawab Bersama antar para stakeholder dan masyarakat. Kebersihan pada setiap daerah pariwisata akan membantu kenyamanam bersama baik itu pengelola, masyarakat, maupun para pengunjung objek wisata. Oleh karena itu, dengan adanya kebun raya ini, 
kedepannya akan memberikan kesadaran bagi masyarakat dalam menjaga kebersihan lingkungan sekitar.

\section{Kesimpulan}

Peran stakeholder dalam pengembangan pariwisata di Kebun Raya Cibinong dibutuhkan untuk membangun Kawasan pariwisata yang dikembangkan sesuai dengan rencana agar dapat berjalan sebagaimana mestinya. Hasil identifikasi stakeholder menunjukan pengelompokan kedalam dua konteks yaitu stakeholder primer yang terdiri dari LIPI dan Pemerintah Kabupaten Bogor, serta stakeholder sekunder yang terdiri dari Kementerian PUPR, Dinas PUPR Kab. Bogor, Mitra Pengelola Kebun Raya, dan Pelaksana TJSL Kab. Bogor. Untuk mendukung keberhasilan dalam pengembangan pariwisata, maka dilakukan analisis peran dari masing-masing stakeholder. Hasil analisis menunjukan para stakeholder terbagi kedalam empat kategori analisis peran berdasarkan kepentingan dan Pengaruh, yakni sebagai Subyek (Pemerintah Kab. Bogor), sebagai Pemain Kunci (LIPI), sebagai Pengikut Lain (Kementerian PUPR, Dinas PUPR Kab. Bogor, Pelaksana TJSL Kab. Bogor), dan sebagai Pendukung (Mitra Pengelola Kebun Raya).

Analisis diatas dijelaskan lebih lanjut pada diagram keterlibatan antar stakeholder dalam mengembangkan sektor pariwisata di Kebun Raya Cibinong. Pembagian peran dan tanggung jawab masing-masing stakeholder dapat mempercepat proses pembangunan sektor pariwisata yang dilakukan di Kebun Raya Cibinong. Dampak dari adanya pembangunan dan pengembangan Kebun Raya Cibinong dapat terlihat dari segi ekonomi, sosial, dan lingkungan. Hal yang paling jelas terlihat adalah adanya peningkatan penyerapan tenaga kerja dan pertumbuhan ekonomi sekitar Kawasan kebun raya, sehingga akan meningkatkan kesejahteraan masyarakat pada umumnya. Selain itu, masyarakat akan lebih peduli pada lingkungan dengan menjaga kebersihan daerah sekitar sehingga akan memberikan kesan positif bagi pengembangan lingkungan di sekitar Kawasan.

Selanjutnya, pengembangan Sektor Wisata bukan hanya di Kebun Raya Cibinong (Ecopark), Potensi Wisata di Kawasan Cibinong Science Center-Botanical Garden menjadi sangat strategis untuk dikembangkan menjadi wisata kebun penelitian seperti sekolah alam ada juga musium Zoologi yang punya koleksi terlengkap dan terbesar saat ini bisa menjadi wisata pendidikan serta kolaborasi Puslit.Limnologi dan Raiser berpotensi untuk wisata danau/setu penelitian dan budidaya pengembangan ikan hias di wilayah kabupaten Bogor. Pengembangan berbagai bidang ilmu baik masih terus bisa dikembangkan dan digali sebagai potensi sektor pariwisata yang, saling berinteraksi lintas lembaga, institusi, organisasi dengan bidang terkaitnya tetap berorientasi mendasar pada pemecahaan masalah masyarakat maupun negara.

\section{Daftar Pustaka}

Amsyari, F. (2018). Kolaborasi antar Stakeholder dalam Pengembangan Pariwisata Religi Sunan Ampel di Kota Surabaya. Kebijakan Dan Manajemen Publik, 6(1), 10-21.

Ansell, C., \& Gash, A. (2007). Collaborative Governance in Theory and Practice. Journal of Public Administration Research and Theory, 18, 543-571.

Bryson, John. M. (2004). What To Do When Stakeholders Matter: A Guide to Stakeholder Identification and Analysis Techniques. Public Management Review.

Dabphet, S. (2006). The key stakeholders in the implementation of sustainable tourism development in two rural towns of Thailand. International Journal of Business Tourism and Applied Sciences, 1-11. http://www.ijbtsjournal.com/images/main_1366796758/0029-Siripen.pdf 
Dwyer, L., \& Edwards, D. (2000). Nature-based tourism on the edge of urban development. $\begin{array}{llll}\text { Journal of Sustainable } & \text { Tourism, }\end{array}$ https://doi.org/10.1080/09669580008667364

Emerson, K., Nabatchi, T., \& Balogh, S. (2012). An integrative framework for collaborative governance. Journal of Public Administration Research and Theory, 22(1), 1-29. https://doi.org/10.1093/jopart/mur011

Febrian, R. A. (2016). Collaborative Governance in The Development of Rural Areas (Review of the Draft and Regulation). Wedana, II, 200-208. http://journal.uir.ac.id/index.php/wedana/article/view/1824 diakses pada tanggal 5 April 2019 pukul 02:55 WIB

Freeman, R. E., Harrison, J. S., \& Wicks, A. C. (2007). Managing for Stakeholders. Yale University Press. http://www.jstor.org/stable/j.ctt1npxrg

Hardiansyah, G. (2012). Analisis Peran Berbagai Stakeholder dalam Menyongsong Era Pembangunan KPH di Kabupaten Ketapang. Jurnal EKSOS, 8(3), 186-194.

Hidayah, N. A., Hutagalung, S. S., Hermawan, D., Ilmu, F., Lampung, U., Februari, D., April, D., Juni, D., \& Pringsewu, K. (2019). Analisis Peran Stakeholder Dalam Pengembangan Wisata Talang Air Peninggalan Kolonial Belanda Di Kelurahan Pajaresuk Kabupaten Pringsewu Peran stakeholder dibutuhkan untuk mengoptimalkan pelaksanaan pembangunan termasuk pembangun. Jurnal Administrasi Publik, 7, 55-71.

Hijriati, E., \& Mardiana, R. (2015). Pengaruh Ekowisata Berbasis Masyarakat Terhadap Perubahan Kondisi Ekologi, Sosial Dan Ekonomi Di Kampung Batusuhunan, Sukabumi. Sodality: Jurnal Sosiologi Pedesaan, 2(3), 146-159. https://doi.org/10.22500/sodality.v2i3.9422

Junaid, I. (2019). Model Sinergi Unsur Pentaheliks Pariwisata Dalam Pengelolaan Destinasi Wisata Kota Parepare Dan Kabupaten Bone. Sosiohumaniora, 21(1), 22. https://doi.org/10.24198/sosiohumaniora.v21i1.17016

Khomzi, I. R., Handono, S. Y., \& Trianawati, A. (2020). Sinergisitas Stakeholder Dalam Pengembangan Desa Wisata Pujon Kidul Kabupaten Malang. Agribusiness Journal, 13(2), 25-35. https://doi.org/10.15408/aj.v13i2.13948

Kuhn, B. (2016). Collaborative Governance for Sustainable Development in China. Open Journal of Political Science, 06(04), 433-453. https://doi.org/10.4236/ojps.2016.64037

Mahfud, M. (2015). Peran Dan Koordinasi Stakeholder Dalam Pengembangan Kawasan Minapolitan Di Kecamatan Nglegok, Kabupaten Blitar. Jurnal Administrasi Publik Mahasiswa Universitas Brawijaya, 3(12), 2070-2076.

Mitchell, R. K., Agle, B. R., \& Wood, D. J. (1997). Toward a Theory of Stakeholder Identification and Salience: Defining the Principle of who and What Really Counts. Academy of Management Review, 22(4), 853-886. https://doi.org/10.5465/amr.1997.9711022105

Pamungkas, G. (2013). Ekowisata Belum Milik Bersama: Kapasitas Jejaring Stakeholder dalam Pengelolaan Ekowisata (Studi Kasus: Taman Nasional Gunung Gede Pangrango). $\begin{array}{lllll}\text { Journal of Regional and City Planning, } 49 . & \end{array}$ https://doi.org/10.5614/jpwk.2013.24.1.4

Purwanti, N. D. (2016). Collaborative Governance (Kebijakan Publik dan Pemerintahan Kolaboratif, Isu-Isu Kontemporer). Yogyakarta: Center for Policy \& Management Studies FISIPOL Universitas Gadjah Mada.

Rahmah, W. (2017). Dampak Sosial Ekonomi Dan Budaya Objek Wisata Sungai Hijau Terhadap Masyarakat Di Desa Salo Kecamatan Salo Kabupaten Kampar. JOM FISIP Vol. 4 No. 1 - Februari 2017, 4(1), 1-16. 
Redyanto, F. W., Salahudin, S., \& Salviana, V. (2018). Model Kerjasama Antar Stakeholders Dalam Pengembangan Wisata Budaya Dusun Sejo Kabupaten Pasuruan. LOGOS (Journal of Local Government Issues), 1-24.

Rizal, A., Sumartik, \& Zulfikar. (2017). Analisa Dampak Ekonomi, Sosial, Lingkungan Terhadap Pengembangan Objek Wisata Banyu Biru Di Desa Sumberejo, Winong, Pasuruan Jatim. Forum Manajemen Indonesia (FMI) KE-9, November 2017, ISBN : 978602-8557-31-3, 1-14.

Sjaifudian, H. (2003). Inovasi, partisipasi, dan good governance: 20 prakarsa inovatif dan partisipatif di Indonesia. Yayasan Obor Indonesia.

Sugiyono. (2010). Metode Penelitian Pendidikan Pendekatan Kuantitatif, kualitatif, dan R\&D. Bandung: Alfabeta.

Wakka, Abd. K. (2014). Analisis Stakeholders Pengelolaan Kawasan Hutan Dengan Tujuan Khusus (KHDTK) Mengkendek, Kabupaten Tana Toraja, Provinsi Sulawesi Selatan. Jurnal Penelitian Kehutanan Wallacea, 47. https://doi.org/10.18330/jwallacea.2014.vol3iss1pp47-55

Wanna, J. (2008). Collaborative government: meanings, dimensions, drivers and outcomes. https://doi.org/10.22459/CG.12.2008.01

Yasintha, P. N. (2020). Collaborative Governance Dalam Kebijakan Pembangunan Pariwisata Di Kabupaten Gianyar. Jurnal Ilmiah Dinamika Sosial, 4(1), 1. https://doi.org/10.38043/jids.v4i1.2219 